\title{
Plasma digoxin concentrations and urinary excretion during a 'simpler' regimen of infant digitalization
}

\author{
M. O. SAVAGE, A. G. HIBBLE, and D. PICKERING \\ From the Department of Paediatrics, Radcliffe Infirmary and John Radcliffe Hospital, and MRC Unit and \\ Department of Clinical Pharmacology, Radcliffe Infirmary, Oxford
}

\begin{abstract}
Savage, M. O., Hibble, A. G., and Pickering, D. (1975). Archives of Disease in Childhood, 50, 393. Plasma digoxin concentrations and urinary excretion during a 'simpler' regimen of infant digitalization. We have measured the plasma concentrations in sick neonates and infants being administered digoxin by a safer regimen. In the presence of normal renal function the plasma concentrations appear to be satisfactory.
\end{abstract}

Infant deaths from digoxin overdosage continue to occur most frequently during initial digitalization. In an attempt to avoid these, a simplified regimen for digitalization of children was adopted in the United Oxford Hospitals (Ellis, Pickering, and Trillwood, 1972). This study was designed to assay plasma digoxin concentrations achieved during digitalization with this dosage scheme. It was subsequently extended to provide further information on the urinary excretion of digoxin in the neonate from Case 5 onward.

\section{Patients and methods}

Patients. 13 infants between the ages of one day and 10 weeks were digitalized for cardiac failure. One infant was digitalized twice, there being an interval of 10 days without digoxin. The digitalization schedule consisted of four intramuscular injections of $0.01 \mathrm{mg} / \mathrm{kg}$ 4-hourly (according to the response of the child). The preparation used was Paediatric Digoxin (Boots Pure Drug Company Ltd.) supplied in $1 \mathrm{ml}$ ampoules, each containing $0.1 \mathrm{mg}$ (100 $\mu \mathrm{g}$ digoxin). The same regimen was used for all infants regardless of age. This scheme allows a total dose to be tailored to the needs of the individual child, while maintaining unitary figures in calculation, prescription, and dispensing. For example: $6 \mathrm{~kg}$ infant, digitalizing dose $0.06 \mathrm{mg}$ 4-hourly $\times 4$ doses intramuscularly depending on response $(0.06 \mathrm{mg}=$ $0.6 \mathrm{ml}$ Paediatric Digoxin measured in a $1 \mathrm{ml}$ Mantoux syringe). Digoxin therapy was then maintained orally with Paediatric Lanoxin $0.01 \mathrm{mg} / \mathrm{kg}$ once or twice daily. Digoxin was witheld if the pulse rate fell below $120 / \mathrm{min}$ during either digitalization or maintenance therapy.

Received 31 October 1974.
Methods. Blood samples from umbilical vein catheter or venepuncture were taken into lithium heparin and centrifuged. The first plasma samples were taken before the administration of digoxin. Subsequent samples were taken at 4-hourly intervals, that is just before the next dose for 12 hours into the digitalization regimen. Samples were then taken at 16 hours, 24 hours, and again at 48 hours.

Plasma samples were stored at $-20^{\circ} \mathrm{C}$ until assayed. Plasma concentrations were assayed by a radioimmunoassay method (Smith, Butler, and Haber, 1969) using rabbit antidigoxin serum (Wellcome) and ${ }^{3} \mathrm{H}$ digoxin (New England Nuclear). Samples were counted in a Wallace-LKB liquid scintillation counter, and quench correction was calculated by substituting the functions of a bilirubin quench curve into the dpm printout facility. Because of the small volume of plasma used $(0.1 \mathrm{ml})$ the degree of quenching was minimized. The quench values for the samples were within the range of the values obtained with the prepared bilirubin quench curve.

In 6 infants a 24-hour urine collection was made from the time of the first digitalizing dose. Urine was collected in U-Bags (Hollister), and collection was complete in each case. Urine in $5 \mathrm{ml}$ volumes was extracted with $10 \mathrm{ml}$ dichloromethane. The aqueous phase was discarded and $8 \mathrm{ml}$ dichloromethane was dried down in a current of air and the dried extract was made up to $4 \mathrm{ml}$ with the assay buffer solution. Doubling dilutions of the extract were prepared and radioimmunoassayed. Parallelism to the standard curve was shown in each case. Using the same procedure extraction of digoxin from urine was between 95 to $100 \%$.

\section{Results}

Following the findings of O'Malley et al. (1973) of higher plasma digoxin concentrations in infants 
aged less than one month, we divided our patients into two groups, namely those younger and those older than one month of age.

The individual results of plasma concentrations during digitalization are shown in Fig. 1 and 2.

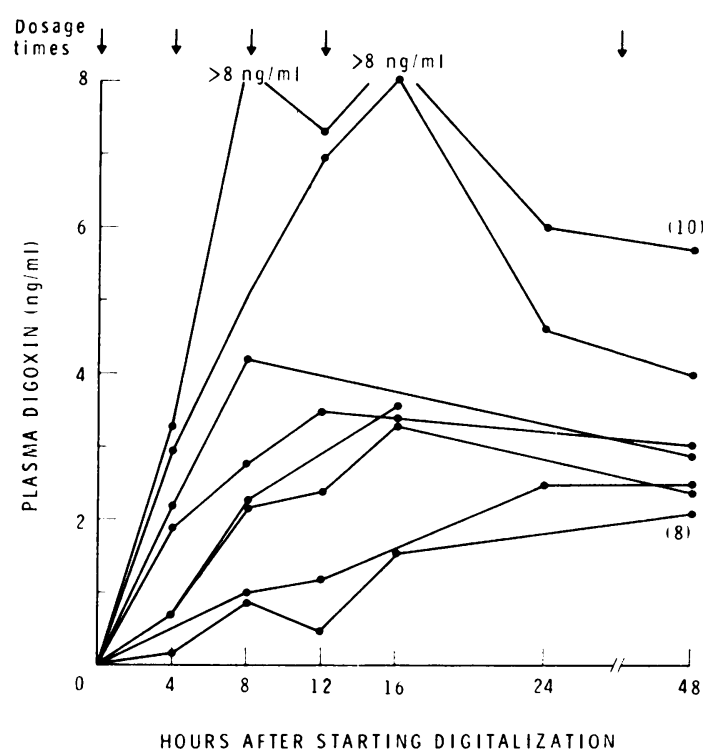

FIG. 1.-Plasma digoxin concentrations of infants under one month of age during a 'simpler' regimen of digoxin administration.

Fig. 1 shows that in infants of less than one month high plasma digoxin concentrations are obtained during digitalization. In only 2 patients did the values fail to exceed $2 \mathrm{ng} / \mathrm{ml}$ during the period of late digitalization, and in one of these (Case 8 ) there was poor clinical response. Case 10 developed bradycardia and a prolonged PR interval 27 hours after the start of digoxin therapy, and 15 hours after the last dose of digoxin. Plasma concentration at

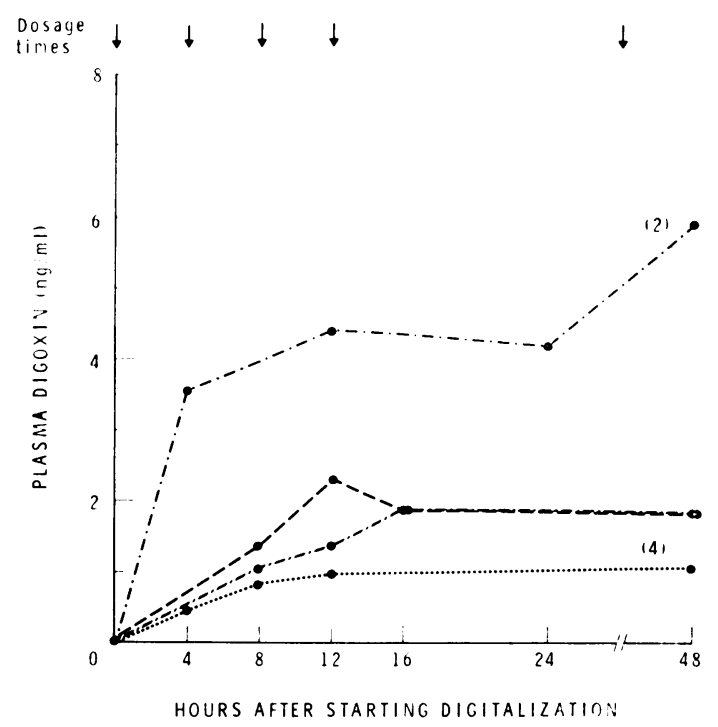

FIG. 2.-Plasma digoxin concentrations of infants over one month of age during a 'simpler' regimen of digoxin administration.

this time was $6 \cdot 0 \mathrm{ng} / \mathrm{ml}$. Subsequently it was found that at 8 and 16 hours during digitalization the plasma concentration was greater than $8 \mathrm{ng} / \mathrm{ml}$. The plasma digoxin concentrations might have been raised because of poor renal function shown by the high blood urea concentration of $50 \mathrm{mg} / 100 \mathrm{ml}$ and a 24-hour urinary volume of only $80 \mathrm{ml}$. However, the 24-hour urinary digoxin excretion in this case is higher than in some infants with lower plasma concentrations (Table). The results from infants older than one month (Fig. 2) show that apart from Case 2 the plasma digoxin concentrations were less than $2.5 \mathrm{ng} / \mathrm{ml}$, i.e. the results represent a spectrum rather than two distinct populations, though tending to be higher in the younger group. The measured amount of digoxin that was ex-

TABLE

Urinary 24-hour digoxin excretion with urine volume, total digoxin dose, and blood urea during simpler regimen of infant digitalization

\begin{tabular}{c|c|c|c|c|c}
\hline Case no. & $\begin{array}{c}\text { Total } \\
\text { digitalizing } \\
\text { dose }(\mu \mathrm{g})\end{array}$ & $\begin{array}{c}\text { Total digoxin in } \\
24-\mathrm{h} \text { urine } \\
\text { collection }(\mu \mathrm{g})\end{array}$ & $\begin{array}{c}\text { Blood urea } \\
\text { concentration } \\
(\mathrm{mg} / 100 \mathrm{ml})\end{array}$ & $\begin{array}{c}\text { 24-h urine } \\
\text { volume } \\
\text { (ml) }\end{array}$ & $\begin{array}{c}\text { Digoxin output } \\
\% \text { of digitalizing } \\
\text { dose }\end{array}$ \\
\hline 6 & 100 & $16 \cdot 73$ & 34 & 240 & 124 \\
7 & 100 & $4 \cdot 61$ & 6 & 125 & $4 \cdot 7$ \\
8 & 100 & $3 \cdot 3$ & 28 & $3 \cdot 3$ & $12 \cdot 6$ \\
10 & 140 & $17 \cdot 6$ & 25 & 220 & $7 \cdot 4$ \\
12 & 120 & $8 \cdot 9$ & 87 & 167 & $4 \cdot 5$ \\
\hline
\end{tabular}


creted in the 24-hour urine collection can be compared with the predicted amount that should appear if the half-life is assumed to be 32.5 hours (Dungan et al., 1972). This predicted value assumes that the plasma and urinary half-lives are similar (Dungan et al., 1972) and that each dose will have its own half-life independent of the other doses (Doherty and Perkins, 1965).

Knowing the time between administration of digoxin and the end of the collection, it is possible to calculate from an exponential curve with a standard half-life, say $32 \cdot 5$ hours (Dungan et al.), the amount of each dose that should be excreted. These can be added to predict the percentage of the total digitalizing dose that should appear in the urine during the first 24 hours.

The predicted percentage of the digitalizing dose that should be excreted in the urine varied from $24 \%$ to $26 \%$. From the Table it can be seen that none of the infants excreted that amount and the estimated half-lives by back substitution range from 50 to 150 hours. The blood urea concentration was raised at $87 \mathrm{mg} / 100 \mathrm{ml}$ in Case 13 and at $50 \mathrm{mg} / 100 \mathrm{ml}$ in Case 10 . In all other infants at the time of urine collection blood urea was normal.

\section{Discussion}

The regimen for digitalization and maintenance therapy recommended by Ellis et al. (1972) has the great advantages of simplified calculations and easy administration. Until this paper, no information has been available as to the plasma levels obtained during this digoxin schedule. As a result of this study we know the range of values we can expect to find, and we know that the concentrations during digitalization are higher than those found in the adult. The plasma levels recorded at the 24and 48-hour times, at least 8 hours after a dose, were also higher than would be expected in the adult. This agrees with Willerson et al. (1970) and O'Malley et al. (1973), who found higher plasma digoxin levels in neonates than adults but without toxic effects.

Case 10, who had very high levels during digoxin administration, showed bradycardia and a pro- longed PR interval suggesting toxicity. The one infant in whom the clinical response was poor, had low plasma levels during digitalization.

The total digitalizing dose of $0.04 \mathrm{mg} / \mathrm{kg}$ is in the same range as that for an adult but the infant doses are given intramuscularly and over a 12-hour period. Digoxin administration to an adult in this fashion would be unusual and so direct comparison is not possible.

We therefore attempted to explore the distribution and excretion in the neonate and to do this in a way which would not alter the clinical management. The method as described is novel, is based on several assumptions, and needs wider validity. As a figure for the half-life so much depends on these assumptions, and as it can only be obtained by such substitution, we have not presented the figures as such. We did find that the amount excreted in 24 hours by the infants was such that the half-lives would be greater than hitherto found by Dungan et al., (1972) and would be in the range of 50 to 150 hours.

We thank Professor J. P. M. Tizard and Drs. H. L. Ellis and B. D. Bower for permission to study patients admitted under their care; and Professor Graham Smith for his help throughout this work. The technical skill of Malcolm Bloomfield is gratefully acknowledged.

\section{REFBRENCES}

Doherty, J. E., and Perkins, W. H. (1965). Studies following intramuscular tritiated digoxin in human subjects. American Fournal of Cardiology, 15, 170.

Dungan, W. T., Doherty, J. E., Harvey, C., Char, F., and Dalrymple, G. V. (1972). Tritiated digoxin XVIII. Studies in infants and children. Circulation, 46, 983.

Ellis, H. L., Pickering, D., Trillwood, W. (1972). Digitalisation of infants. Lancet, $2,325$.

O'Malley, K., Coleman, E. N., Doig, W. B., and Stevenson, I. H. (1973). Plasma digoxin levels in infants. Archives of Disease in Childhhood, 48, 55.

Smith, T. W., Butler, V. P., and Haber, E. (1969). Determination of therapeutic and toxic serum digoxin concentrations by radioimmunoassay. New England fournal of Medicine, 281 1212.

Willerson, J. T., Rogers, M., Goldblatt, A., and Smith, T. W. (1970). Serum digoxin levels in children. (Abst.) American fournal of Cardiology, 26, 666.

Correspndence to Dr. D. Pickering, Department of Paediatrics, the Radcliffe Infirmary, Oxford OX2 6HE. 